\title{
The Implementation of Biogas Production from Municipal Solid Waste in Nigeria
}

\author{
Jimento Aikhuele ${ }^{1,3}$ Victor Eniola ${ }^{2,3}$ Alero Aikhuele ${ }^{4 *}$ Olatubosun Fasipe $^{3}$ Nathan Awuapila $^{3}$ \\ 1. Department of Environmental Resource Engineering, Humboldt State University, Arcata, CA 95521, USA \\ 2. School of Renewable Energy and Smart Grid Technology, Naresuan University, Phitsanulok 65000, Thailand \\ 3. Energy Commission of Nigeria, Plot 701C, Central Business District, P.M.B. 358, Garki, Abuja 900211, Nigeria \\ 4. \\ Department of International Development Community and Environment, Clark University, MA 01610, USA \\ * E-mail of the corresponding author: a.aikhuele@gmail.com
}

\begin{abstract}
The deployment of clean energy systems has increased over the years as a result of the attendant effects of convectional fuel-based plants. A good set of goals, inclusive of clean and affordable energy initiative, have been set and implemented in many developing countries by the United Nations. However, the commitment to reduce greenhouse emission with clean energy technologies in Nigeria has faced several implementation challenges. This study presents a technical and economic feasibility analysis of an $8 \mathrm{~m}^{3}$ fixed-dome family biogas digester to replace the use of fuelwood in rural community households in selected states of the six geopolitical zones of Nigeria. Based on the economic analysis from the results, the use of biogas-digester is more economically viable with a quick return on investment, low maintenance cost, and availability of raw materials at little or no cost. The results also revealed other benefits such as avoided greenhouse gas (GHG) emission, reduced deforestation due to very low dependence on fuelwood, health benefits; eliminating hazardous particulate matter, fatigue, and health conditions for women and children as a result of long-distance travelled and hours spent fetching fuelwood. Additionally, the time wasted in collecting fuelwood can be reduced and maximized for other gainful and laudable activities such as learning. This paper recommends sustainable policies pertinent to the development and proliferation of biogas plants in rural communities of Nigeria. Following the 2013 economic rebasing, Nigeria happens to be the West African country with the largest economy. Considering the robustness of the country's economy, public and private investments in clean technologies like biogas system, will not only help us meet household demands but also consolidate the energy sector, thereby opening many opportunities. Therefore, the significance of this study is that many households in rural populace would be empowered to meet their energy demand and reduce dependence on fuelwood. There are existing economic, regulatory and institutional frameworks to sustain this transformation, and Nigeria will witness the change it sets to achieve.
\end{abstract}

Keywords: clean technology, biogas, municipal waste, economic analysis, policy

DOI: $10.7176 / \mathrm{JETP} / 10-1-06$

Publication date: February $29^{\text {th }} 2020$

\section{Introduction}

In New York, the United States of America, the Nigerian president addressed a conference on "Taking Climate Action for Sustainable Development"; jointly organized by United Nations Environment Program (UNEP) and the Nigerian Government. After signing the Paris Climate Change Agreement, the president of Nigeria, Muhammadu Buhari stated that his consent to the agreement expressed the obligation of Nigerian Government to global efforts to refute catastrophic climate change. "Nigeria is committed to reducing greenhouse gas (GHG) emissions unconditionally by $20 \%$ and conditionally by $45 \%$ ", the president said (Uwaegbulam \& Daka 2016).

The policy statement may be achievable through the implementation of clean or alternative energy technology. Biogas technology could be utilized to achieve this goal, and a proposal should be channelled through the appropriate government body, i.e., the Energy Commission of Nigeria (ECN) or other relevant ministries, departments or agencies for proper project implementation and adequate funding. The statements directly above are authors' reflection, and they are articulated to give guidance to the readers, investors or relevant stakeholders on the channel that can be used to drive the initiative.

The digestion of organic matters in an anaerobic system, called a digester, results to the production of biogas. The organic matters could be substrates, which classically comprise wastes from kitchen, human excrement, animal waste (cow dung, chicken manure etc.), wastewater, or residues from agricultural processes. All these are readily 
available in rural community households in Nigeria. The most used biogas system in households is the fixed-dome model. This type of biogas system is inexpensive in terms of construction, as it is built using locally available materials (Wargert 2009). In order to conserve space, it is built underground; with an added advantage of less exposure to recurrent changes in temperature (Sasse 1988). In 1998, the Energy Commission of Nigeria's Sokoto Energy Research Center (ECN-SERC) built a $20 \mathrm{~m}^{3}$ fixed-dome bio-digester. The system utilizes pig dung to generate its biogas and organic fertilizer, which a good number of community inhabitants use for cooking/water heating and as farm manure respectively (Dioha et al. 2012).

This brief examines the potential of providing clean fuel by converting organic waste to biogas in households in rural areas of Nigeria at an affordable cost. The objectives of this project proposal are:

- $\quad$ To reduce fuelwood emissions from rural areas by $50 \%$ in 2025 ;

- To increase demand for biogas to $40 \%$ in rural communities by 2025 ;

- To reduce health hazards associated with the use of wood as fuel in rural communities.

As a reminder, the rest of this paper is organized as follows: sections II presents the demographics and energy resources in Nigeria, section III articulates the study approach and details the findings, the benefits of the proposal implementation are expounded in section IV, whereas section $\mathrm{V}$ concludes the entire paper alongside recommendations.

\section{Demographics and Energy Resources in Nigeria}

In the continent of Africa, Nigeria happens to be the most populated country, with over 190.9 million people. Good people, great nation. About 52\% live in rural areas, according to the World Bank estimates. Nigeria has an abundant primary resource (organic waste), but it is not being deployed as an energy resource. The Solar Cooking Archive (SCA 2011) estimated that fuelwood utilization in Nigeria represents $87 \%$ of all fuel consumption. The share of this GHG-producing energy source is very high, in comparison with what is seen today in developed countries in Europe for instance. Germany has more than $42 \%$ of its energy production from renewable sources inclusive of solar and wind. Currently, the country has issued a policy to completely wipe out diesel engines, and there are existing energy masterplans to achieving $100 \%$ renewables. There have been cases when their renewable energy sources generated more than their demand. Energy storage systems were charged, and end-users were motivated to consume energy at negative costs. Also, Denmark has more than $70 \%$ of its energy generation from renewable sources, by leveraging on wind power. These are sustainable part ways to environmentally sound and cleaner future. Nigeria, as a developing country, can emulate some of these strategic plans, by establishing policy frameworks that will drive and sustain the use of biogas for cooking and water heating in all rural communities.

Most of the fuelwood consumption in Nigeria is from rural communities. At the same time, 18.5 million tons of municipal waste has not been utilized (ECN 2010). In Nigeria, the daily production of new livestock waste is being estimated at 227,500 metric tons (Igboro 2011; Ahmadu et al. 2009). Besides, (Nwude et al. 2010) estimated the daily generation of municipal solid waste at $20 \mathrm{~kg}$ per capita. Going by Nigeria's 1991 population census figure of 88.5 million people, an estimate of 1.8 million metric tons of municipal solid waste is or was? generated daily (Igboro 2011). Given that $1 \mathrm{~kg}$ of fresh livestock waste produces approximately $0.03 \mathrm{~m}^{3}$ of biogas, Nigeria has the potential of producing nearly 6.8 million $\mathrm{m}^{3}$ of biogas per day; from livestock waste alone (Ahmadu et al. 2009; Igboro 2011).

\section{Study Approach and Results}

\subsection{Project Location and Raw Material}

The project shall be implemented in rural community households in each selected state in the six geopolitical zones. The raw materials for the biogas plant will be sourced from food and animal wastes from households. The location choice is strategic due to larger populations in the local government areas, and the amount of fuelwood and raw materials for biogas production consumed in areas with higher population density. Using census estimates for each zone, states, and communities with higher population would help determine the optimal consumption of fuelwood and resources for biogas plants. Demographics are as presented in Table 1. Fuelwoodutilization by the rural populace in Nigeria is estimated to be about 27.5 million $\mathrm{kg}$ /day (Ogunsanwo \& Ajala 2002). Estimates of Nigerian fuel consumptions are as given in Table 2. 
Table 1. Different geopolitical zones and their population

\begin{tabular}{|l|l|l|l|}
\hline Geopolitical Zone & State & Local Government Area & Population \\
\hline North Central & Nasarawa & Karu & 205,477 \\
\hline North East & Adamawa & Demsa & 206,215 \\
\hline North West & Kaduna & Birnin- Gwari & 300,430 \\
\hline South East & Anambra & Idemili North & 495,770 \\
\hline South South & Edo & Oredo & 428,650 \\
\hline South West & Oyo & Ibadan & 856,988 \\
\hline
\end{tabular}

Source: Census (2006). Nigerian National Population Commission -NPC

Table 2. Fuel wood consumption for Nigeria's six geopolitical Zones

\begin{tabular}{|l|l|l|l|}
\hline $\begin{array}{l}\text { Daily Consumption } \\
\text { of } \\
\text { (ton/day) }\end{array}$ & $\begin{array}{l}\text { Total Population } \\
\text { of } \begin{array}{r}\text { Rural } \\
\text { Communities }\end{array}\end{array}$ & $\begin{array}{l}\text { Total Population of } \\
\text { the Six } \\
\text { Geopolitical Zones }\end{array}$ & $\begin{array}{l}\text { Daily Consumption of } \\
\text { Fuelwood in the Six } \\
\text { Geopolitical Zones } \\
\text { (ton/day) }\end{array}$ \\
\hline 27,500 & $94,744,000$ & $24,935,30$ & 724 \\
\hline
\end{tabular}

\subsection{Challenges of Using Fuelwood}

One of the major challenges faced in Nigeria is that most rural area dwellers use wood as fuel for cooking and lighting despite the available energy resources i.e., organic waste for biogas. Uncontrolled used of fuelwood can result to problems associated with health challenges, deforestation, rising climate change, and flooding. Case studies of these challenges conclude that:

- $\quad$ Fuelwood use in developing countries is responsible for 54\% of the world's deforestation (Osei 1993).

- Deforestation is a major source of GHG gases. It is accountable for $17-25 \%$ of all anthropogenic GHG gas emissions worldwide. (Strassburg et al. 2009).

The burning of fuelwood creates hazardous particulate matter. These hazardous particles have been acknowledged as a detrimental factor contributing terrifically to child mortality. Another typical particle- related health hazard is an eye ailment. (Bajgain \& Shakya 2005). Additionally, long travel distances from fetching firewood contribute to the challenges being faced by women and children in fatigue and health conditions. In rural areas of Nigeria, women and children spend several hours fetching firewood, time which they could spend in activities that can empower them and enrich their future (Premium times 2013).

\subsection{Dealing with the Problems of Excessive Use of Fuelwood}

There are many potential alternatives to the use of fuelwood. However, they are subject to resource availability, initial capital costs, accessible funding and technical know-how. One technology that has proven worthwhile in rural communities of developing countries is biogas utilization. Both government institutions and households in Nigerian communities have the dual advantages of stakeholder involvement and resource availability. China, India, and Nepal have all implemented biogas technology. In rural communities of developing countries, biogas utilization has proven to be an essential scheme in solving the problems of energy demand (Wargert 2009). Biogas can aid clean and sustainable cooking without the effects of dangerous particles specifically produced by fuelwood and it can also be used to produce electric power or heat (Bajgain et al. 2005).

In Rwanda, 250 units/month is targeted with a GDP of 29.7 billion dollars to a population of 12 million. (Rakotojaona 2013). The biogas digesters in Nigeria were installed as pilot projects. The most installed is the fixed-dome, requiring at least a mason and a plumber. Table 3 compares different biogas plants types used in Rwanda and Nigeria. A benefit-to-cost analysis has been implemented for installing an $8 \mathrm{~m}^{3}$ family-sized biogas digester in Nigeria, and the results are as summarized in Table 4. Figure 1 presents the sensitivity analysis of the lifecycle cost and the net present value (NPV) at various discount rates for the $8 \mathrm{~m}^{3}$ family-sized biogas-digester, 
whereas figure 2 shows a sensitivity analysis on O\&M cost at different percentages on the upfront cost. The savings from avoided fuelwood use, the assumptions used for the analysis, the sizes of various fixed-dome biogas and the required raw material are presented in Appendix A; while the information used for the GHG gas emission analysis is given in Appendix B.

Table 3. Comparison of different biogas plants types (a case study of Rwanda and Nigeria)

\begin{tabular}{|c|c|c|}
\hline Technology & Pros & Cons \\
\hline \multirow{3}{*}{$\begin{array}{l}\text { Plastic } \\
\text { digester }\end{array}$} & $\begin{array}{l}\text { - Inexpensive technology. } \\
\text { - Between (USD } 130-200) \text {. }\end{array}$ & Very damageable. \\
\hline & Widely available. & $\begin{array}{l}\text { - Not as durable as traditional digesters. } \\
\text { - Short lifespan: } 4 \text { years maximum. }\end{array}$ \\
\hline & $\begin{array}{l}\text { Easy to check how much gas is } \\
\text { available. }\end{array}$ & $\begin{array}{l}\text { Low gas pressure. Time of production is } \\
\text { greatly reliant on ambient temperature. }\end{array}$ \\
\hline $\begin{array}{l}\text { Fixed dome } \\
\text { technology } \\
\text { (Analysis based } \\
\text { on designs in } \\
\text { Rwanda and } \\
\text { Nigeria) }\end{array}$ & $\begin{array}{l}\text { - Long lifespan of more } \\
\text { than } 20 \text { years. } \\
\text { - Not damageable (underground). }\end{array}$ & $\begin{array}{l}\text { - Expensive technology. Between (USD } \\
870-1,500 \text { ) in Rwanda } \\
\text { and (USD } 1,400-1,900 \text { ) in Nigeria for } \\
\text { a } 10 \mathrm{~m}^{3} \text { bio-digester. }\end{array}$ \\
\hline
\end{tabular}

Source: (Dioha et al. 2012 \& Rakotojaona, 2013).

Table 4. Summarized result of the economic analysis of an $8 \mathrm{~m}^{3}$ family-sized bio-digester in Nigeria

\begin{tabular}{|c|c|c|c|c|c|}
\hline $\begin{array}{l}\text { Total Installation } \\
\text { Cost } \\
\text { (A) }\end{array}$ & $\begin{array}{l}\text { O\&M } \\
\text { Cost } \\
\text { (A) }\end{array}$ & $\begin{array}{l}\text { Discounted } \\
\text { Payback Period } \\
\text { (Years) }\end{array}$ & $\begin{array}{l}\text { Net Present Value } \\
\text { (\#) }\end{array}$ & $\begin{array}{l}\text { Life Cycle } \\
\text { Cost } \\
\text { ( })\end{array}$ & $\begin{array}{lr}\text { Internal Rate } \\
\text { of } & \text { Return } \\
(\%) & \end{array}$ \\
\hline 525,000 & 10,500 & 3 & $967,320.00$ & $\begin{array}{l}1,268,586.8 \\
8\end{array}$ & 46 \\
\hline
\end{tabular}

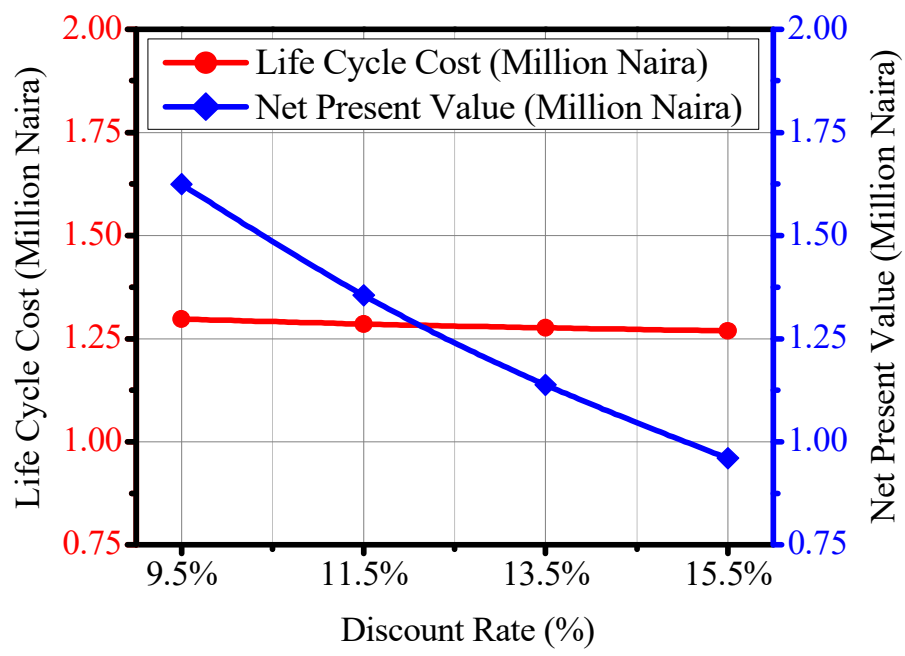

Figure 1. Lifecycle cost and NPV at various discount rates for the $8 \mathrm{~m}^{3}$ family sized biogas-digester 


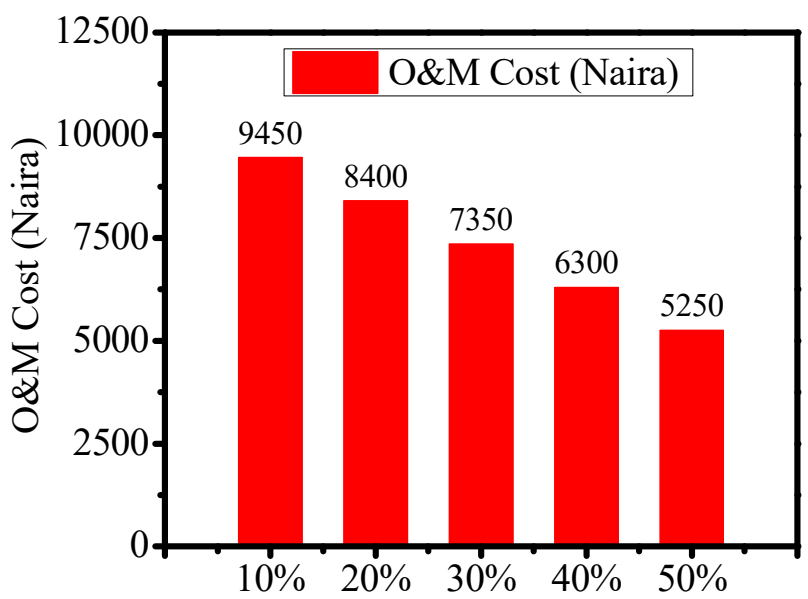

\section{Percentage on Upfront Cost (\%)}

Figure 2. Sensitivity analysis on O\&M at different percentages on the upfront cost

\section{Benefits of Proposal Implementation}

Reduced costs, improvement of health and control measures against environmental hazards are the core

benefits of this project. Other essential benefits are reducing time wastage in collecting fuelwood, combating deforestation, as well as reducing reliance on fossil fuel; such as kerosene, for cooking. The use of biogas can also mitigate net GHG gas emissions. Based on the results of the analyses, an estimated $19 \mathrm{tCO}_{2}$ equivalent would be avoided annually using a single-family $8 \mathrm{~m}^{3}$ biogas digester. The analysis of GHG avoided emissions is as presented in Appendix B.

\section{Conclusion and Recommendation}

Biogas technology remains one of the decentralized alternative energy sources that could be used to replace the use of fuelwood, especially for families living in the rural areas of developing countries like Nigeria. The findings from this study indicated that biogas utilization, efficiency, and cost are no longer in doubt to totally eradicate the use of fuelwood in rural communities of Nigeria. The raw materials are easily obtained from the people's domain. The benefit-to-cost analysis revealed that without any form of grants or subsidy, the payback period is about 3 years for an $8 \mathrm{~m}^{3}$ family-sized biogas digester. Also, a positive NPV and an internal rate of return (IRR) greater than the discount rate ascertains the viability of the project. Additionally, if the biogas system is operated for a period of 330 days in a year; a benefit-to-cost ratio (BCR) of about 3.91 justifies the suitability of the system in meeting rural energy demand.

Therefore, it is recommended that the Government should consider playing an active role in biogas projects using credible policy tools that support and consolidate the unfailing provision of subsidy or flexible re-payment structure for the massive deployment of biogas in communities that cannot afford it. Education and training should also be embraced to create more awareness on the use of biogas.

In this research study, not all aspects of the economic analysis were reflected. Future work should consider assessment integrating business investment for entrepreneurs, as well as upscaling of biogas digester both in the rural and urban areas of Nigeria.

\section{References}

Ahmadu, T.O., Folayan, C.O. \& Yawas, D.S. (2009): "Comparative Performance of Cow Dung and Chicken Droppings for Biogas Production". Nigerian Journal of Engineering, vol. 16, no.1, Faculty of Engineering, ABU, Zaria, pp. 154-164.

Bajgain, S., Shakya, I. (2005). “The Nepal Biogas Support Program: A Successful Model of Public-Private 
Partnership for Rural Household Energy Supply". Ministry of Foreign Affairs, The Netherlands.

Census (2006). Nigerian National Population Commission -NPC.

Dioha, E., Dioha, J., and Nfor, B. (2012). “Operating and Financing a Family Biogas Plant”. Journal of Energy Technologies and Policy. Vol.2, No.5, 2012

Energy Commission of Nigeria (2010). "Renewable Energy Master Plan”. National Committee on Energy, Federal Republic of Nigeria.

Global Alliance for Clean Cook stoves (2011). "Nigeria Market Assessment Sector Mapping”. Retrieved from http://cleancookstoves.org on November 20, 2018.

Gomez, D.R. \& Watterson J.D. (2006). "IPCC Guidelines for National Greenhouse Gas Inventories". Energy Volume 2, page 2.17-2.19. Retrieved from http://www.ipcc-nggip.iges on December 5, 2019.

Igboro, S.B. (2011): "Production of Biogas and Compost from Cow Dung in Zaria". Unpublished PhD Thesis. Department of Water Resources and Environmental Engineering, ABU, Zaria, pp. 1-105.

Liua, G., Lucas, M., Shen, L. (2008); "Rural Household Energy Consumption and its Impacts on Ecoenvironment tin Tibet: Taking Taktse County as an example"; Renewable and Sustainable Energy Reviews $12,1890-1908$.

Nwude, M.O., Umar, M.I., Igboro, S.B \& Okuofu C.A. (2010): "Evaluation of Solid Waste Management in Kaduna Metropolis, Nigerian". Biological and Environmental Science Journal for the Tropics. Vol.7, No.1 Bayero University, Kano.

Ogunsawa O.Y., Ajala O. (2002). "Firewood Crises in Lagos-implication on the Suburban and Rural Ecosystem Management. In: JE Abu, Pooni, L. Popoola (eds). Proceeding of the 28th Annual Conference of Forestry Association of Nigeria at Akure, Ondo State, Nov. 4th - 8th. pp. 257- 264.

Osei, W.Y. (1993). "Wood Fuel and Deforestation - Answers for a Sustainable Environment". Journal of Environmental Management 37, 5162.

Premium Times. (2013). Firewood smoke is the third-largest killer of women, children in Nigeria.

Retrieved from

http://www.premiumtimesng.com/news/124320-firewood-smoke-is-third-largest-killer-of-women-childrenin-nigeria-who.html on October 5, 2019.

Rakotojaona, (2013). "Domestic Gas Development in Developing Countries". Retrieved from http://www.enea-consulting.com on October 5, 2019.

Samer. M. (2012). "Biogas Plant Constructions". Cairo University, Faculty of Agriculture, Department of Agricultural Engineering, Egypt.

Sasse L. (1988). "Biogas Plants: A Publication of the Deutsches Zentrum für Entwicklungstechnologien GATEin": Deutsche Gesellschaft fürTechnische Zusammenarbeit (GTZ) GmbH.

Strassburg, B., Turner, R.K., Fisher, B., Schaeffer, R., Lovett, A. (2009). "Reducing Emissions from Deforestation - the Combined Incentives Mechanism and Empirical Simulations". Global Environmental Change 19 (2009) 265-278.

Shailesh (2012). Environment, GHG mangement Tagged Biomass cooking stoves, Carbon emission from burning of woody biomass, GHG emission, Improved Chullahs. Retrieved from http://greencleanguide.com/how-to-calculate-carbon-emissions- from-a-fuel-wood-cooking-stove/. on December 5, 2019.

The Solar Cooking Archive (2011,). "Fuel Wood as Percentage of Energy Consumption in Developing Countries". Retrieved from http://solarcooking.org/fuelwood.html. on November 20, 2018

Uwaegbulam, C. \& Daka, K. (2016). Buhari signs Paris Agreement on Climate. Guardian Newspaper. Retrieved from https://guardian.ng/news/buhari-signs-paris-agreement-on-climate/on November 20, 2018.

Wargert, D. (2009). “Biogas in Developing Rural Areas”. Lund University Department: Environmental and Energy Systems Studies. Sweden. Retrieved from http://www.davidwargert.net/docs on November 20, 2018.

Jimento Aikhuele became a corporate member of the Nigerian Society of Engineers (NSE) in 2012, a member of the European Energy Centre (MEEC) in 2013, and a registered member of the Association of Energy Engineers (AEE), USA, in 2018. He was 
born in Edo State, Nigeria in 1982. Jimento bagged a Master of Science degree in Energy Technology and Policy from Humboldt State University, USA in 2018. He has an excellent background in chemical engineering from the University of Benin, Nigeria. So far, he has contributed considerably to the growth of the energy field with his fourteen years of work experience as a Process/Safety Engineer in Zico Oil and Gas (2006), a Senior Energy Analyst in the Energy Commission of Nigeria (2011), a Research Assistant in Schatz Energy Research Centre, Humboldt State University, USA (2016), and a Technical Renewable Energy Analyst in RC Cubed, USA (2019). His cognate experience and academic excellence earned him the Schatz Energy Research Center fellowship recipient for two years. In his pursuit for professional competence in the field of energy, he has attended international training programs on Clean Technologies at the Weitz Center for Development Studies in Israel, were his proposal on cleantech emerged the best among 19 countries in participation. He received the NEBOSH International General Certificate in Occupational Health and Safety, UAE, 2014, the Galileo Masters Certificate Training on Energy Efficiency in Buildings. Other programs attended are the International Energy Agency Training on Energy Statistics, 2013 in Paris, France, Summit on Energy and Sustainable Economic Growth in Nigeria, 2012. Jimento has also been involved in some projects in Nigeria in the area of clean technology development, improving energy efficiency in residential buildings as a means of sustainable development in Nigeria, and Solar PV and storage projects in USA.

Victor Eniola became a corporate member of the Nigerian Institution of Mechanical Engineers (NIMechE) in 2014, and a registered Engineer with the Council for Regulation of Engineering in Nigeria (COREN) in 2016. He was born in Ondo State, Nigeria in 1983. Victor graduated from Naresuan University, Thailand, where he obtained a Master of Science degree in 2019 with High Distinction in renewable energy. In 2010, he completed his undergraduate study with First Class honours in mechanical engineering from Obafemi Awolowo University, Nigeria and worked as a Teaching Assistant in University of Benin, Nigeria before joining the Energy Commission of Nigeria (ECN) in 2013. He attended a training program on Renewable Energy as a Catalyst for Regional Development organized by MASHAV, Israel's Agency for International Development Cooperation. In his quest for professional expertise, he has attended many other international training and conferences, including the international training on Wind Turbine Technology and Applications organized by the Ministry of New and Renewable Energy, India. He is currently a Senior Scientific Officer in ECN, actively involved in cutting-edge research in the area of renewable energy technologies. His cognate experience and academic prowess have earned him a recommendation for the Naresuan University President's Graduate Scholarship to undertake doctoral research in Renewable Energy and Smart Grid Technology.

Alero Aikhuele became a corporate member of the West Africa Network of Emerging Leaders in Health Policy and Systems (WANELHPS) in 2019. She was born in Delta State, Nigeria in 1989. Alero is currently pursuing a Masters in community and global health at Clark University, USA. Her work experience and academic accomplishments earned her a graduate scholarship to the program. She graduated from the University of Benin, Nigeria, where she earned a B.A in international studies and diplomacy in 2012. She started her career at the National food and drug Administration (NAFDAC) as an Administrative Assistant. Alero has a great passion for issues relating to climate change, and actively involved in research to better the health of people living in rural communities and developing nations.

Olatubosun Fasipe became a corporate member of the Nigerian Society of Engineers (NSE) in 2012, and a registered Engineer with the Council for Regulation of Engineering in Nigeria (COREN) in 2013. He was born in Ondo State, Nigeria in 1982. Olatubosun bagged a Master degree in 2014 and currently at the verge of completing his Doctoral research in water resources and environmental health engineering from the University of Benin, Nigeria. Prior to joining Energy Commission of Nigeria (ECN) in 2011, he worked with some indigenous construction/oil and gas companies where he acquired a sound knowledge of civil works. He has attended many training programs, both local and international, on hydropower system. He has also done excellent research works on the development of alternate hydropower system. He is currently a Senior Scientific Officer in ECN whose responsibility is not only limited to hydropower projects but also to quantify energy consumption with a view of establishing a baseline for energy need or use in a sustainable manner. His interest in career development has taken him to the Weitz Centre for Sustainable Development, Rehovot, Israel to undertake training on Clean Energy Technologies.

Nathan Awuapila became a member of the World Society of Sustainable Energy Technologies in 2012 and a corporate member of the Nigerian Institute of Physics in 2014. He was born in Benue State, Nigeria in 1981. Nathan has an exceptional background in physics, and presently he is at the verge of completing his Master's degree in environmental physics at the University of Agriculture, Makurdi, Nigeria. He joined the Energy Commission of Nigeria (ECN) in 2010. His academic pursuit has professed a strong educational and ethical philosophy. He attended international training programs on Green Growth-Policy Measures and Implementation Tools in 2014 at the Weitz Center for Development Studies in Israel where he jointly developed an outstanding proposal on "Effective Facility Management for Sustainable Production and Consumption in Abattoirs, Nicaragua". Other training 
programs attended include the Nuclear Security Culture and Methodologies for Securing Nuclear and Radiological Materials, Abuja, 2018; Green Energy for Low Carbon Society, Chiang Mai, Thailand 2019; Small Hydropower and Sustainable Development of Rural Communities, Hangzhou, China, 2019. He is currently a Senior Scientific Officer in ECN, and his responsibilities entail the development of strategic plans and the coordination of national energy policies, different scenario plans for sustainable consumption of the nation's energy resources through modeling and projections of present and future energy demand, and environmental impacts assessment (EIA) using special energy modeling tools. Nathan is also involved in regular monitoring and evaluation visits to the ECN's renewable energy and energy efficiency projects in Nigeria.

\section{Appendix A}

Table A1. Breakdown of fuelwood usage and cost

\begin{tabular}{|l|l|l|l|l|}
\hline Fuel & Purchase Unit & Usage & $\begin{array}{l}\text { Cost for Meal per } \\
\text { day ( }\end{array}$ & $\begin{array}{l}\text { Cost for Meal per } \\
\text { day (USD) }\end{array}$ \\
\hline Wood & $9 \mathrm{~kg}$ & 3 square meals & 350.00 & 0.97 \\
\hline Kerosene & 1.5 litres & 3 square meals & 345.00 & 0.96 \\
\hline Total & 695.00 & 1.93 \\
\hline
\end{tabular}

Note* Exchange rate $\$ 360$ (NGN) to \$1 (USD)

Table A2. Key economic assumptions

\begin{tabular}{|l|l|}
\hline Upfront Cost & $525,000.00$ \\
\hline Discount Rate & $13.5 \%$ \\
\hline O\&M & $2 \%$ on upfront cost \\
\hline Savings from Fuelwood per Year & $229,350.00$ \\
\hline Terms or Lifetime & 20 years \\
\hline
\end{tabular}

Table A3. Required raw material, size of digester and number of family members

\begin{tabular}{|l|l|l|l|}
\hline $\begin{array}{l}\text { Number of } \\
\text { Persons in the } \\
\text { Family }\end{array}$ & $\begin{array}{l}\text { Required Biogas for } \\
\text { Cooking and Lighting } \\
\left(\mathbf{m}^{3}\right) \text { per day }\end{array}$ & $\begin{array}{l}\text { Volume of Digester } \\
\text { Required } \\
\left(\mathbf{m}^{3}\right)\end{array}$ & $\begin{array}{l}\text { Number of Cattle } \\
\text { Needed. }\end{array}$ \\
\hline $7-9$ & 2 & 8 & $5-7$ \\
\hline $10-13$ & 2.5 & 10 & $7-9$ \\
\hline $19-25$ & 5 & 20 & $13-15$ \\
\hline
\end{tabular}

Source: (Dioha et al. 2012).

\section{Appendix B}

Table B. Summarized result of avoided GHG

\begin{tabular}{|l|l|l|l|}
\hline Pollutants & $\mathrm{CO}_{2}$ & $\mathrm{CH}_{4}$ & $\mathrm{NO}_{2}$ \\
\hline Annual tCO2 Equivalent & 19 & 0.02 & 0.10 \\
\hline
\end{tabular}

Total $\mathrm{tCO}_{2}$ equivalent $=19$, which is estimated based on the formula given below; using calorific values and emission factors is retrieved from

https://www.epa.gov/sites/production/files/2015-07/documents/emission-factors_2014.pdf on December 20, 2019.

Source: (Shailesh 2012)

Carbon emission from the non- renewable woody biomass
Quantity of non-

$=$ renewable biomass
X Net calorific value of the non-renewable biomass
$\mathrm{CO} 2$ emission

$\mathrm{X}$ factor for the biomass fuel 